\title{
Nothing Succeeds like Success: The Past and Future of European Political Science
}

\author{
GERALD SCHNEIDER
}

$\mathrm{N}$ ine years ago, I organized a workshop called "Why is European political science so unproductive and what should be done about it" (Schneider 2007). One colleague was, to say the least, a bit outraged and remarked: "This is the most arrogant title of the entire conference," which happened to be a convention of the European Consortium for Political Research (ECPR) in Budapest. I would like to admit two things almost a decade later. First, the title I chose for this academic event was indeed slightly preposterous, but I exaggerated my assessment to make the point that European political science, especially its continental variant, is awfully conservative and not sufficiently internationalized. Second, and more importantly, there is growing evidence that I was at least partly wrong. European political science was already then catching up and is now in many subfields on a par with North America. You might object that my current evaluation is overly rosy. Indeed, a president of an academic organization risks becoming very unpopular among its members if he or she tells them how badly they are all doing. Such a dark message is obviously not what I intend to communicate in this wonderful city with its distinguished tradition in science and philosophy.

I will, on the contrary, present some evidence that justifies my new optimism. My address will advance in four steps. First, I will introduce some reasons why political science after World War II originated as an "American social science," as Hoffmann (1977) controversially argued for international relations, one of our sub-disciplines. My discussion of our joint past will identify three root causes of the malaise that destroyed the nascent modern field before World War II and that has held European political science back for a long time after 1945: fascism, underfunding and disrespect for academic standards. I will present in a second step some evidence from the Social Science Citation Index that European political scientists have become increasingly productive and effective. As I will demonstrate, some countries have overtaken the United States and Canada on a per capita basis in research efficiency. Third, I will show that not only the financial resources devoted to higher education matter. The macro-quantitative evidence I have assembled demonstrates that the organization of the educational system is equally important for the achievements of European political science. I will conclude that an increasing orientation toward competiveness and the growing Europeanization of the job market bode well for our future.

In other words, I am confident that European political science will continue to be a success. Merton's (1968) "Matthew Effect," according to which nothing succeeds like success in

Gerald Schneider is Professor of Political Science, Department of Politics and Public Administration, Box 86, University of Konstanz, 78457 Konstanz, Germany (Gerald.Schneider@uni-konstanz.de) and the $2^{\text {nd }}$ president of the European Political Science Association (EPSA) (2013-15). This article is based on his Presidential Address delivered on 19 June 2014, during the $4^{\text {th }}$ Annual Meeting of the EPSA at the Royal College of Physicians of Edinburgh. The author would like to thank Ken Benoit and Vera Tröger for comments, Michael Bolle and Oliver Fläschner for unearthing details about "elevator professors," and Johann Maier for research assistance. Data and code for the analysis can be found at http://www.polver.uni-konstanz.de/en/gschneider/working-papers/replication-data/. To view Supplementary material for this article, Please visit http://dx.doi.org/10.1017/psrm.2014.17 
academia, will leave its mark if we are able to strengthen our academic organizations and reach out to key decision makers. Hence, building an even stronger European variant of political science requires that we convince institutions like the European Research Council that we are doing important research and that we carry on submitting key articles to European flagship outlets such as EPSA's Political Science Research and Methods.

\section{FORGOTTEN ROOTS AND THE PROBLEMS AFTER WORLD WAR II}

Let me start my address by digging into the past and the destruction of what might have become European political science in the 1920s and early 1930s. Of course, European political science did not exist as a discipline in the early $20^{\text {th }}$ century, although Aberystwyth University founded a department of international politics in 1919, Lund University inaugurated a political science department in 1877, and Uppsala University Chancellor Johan Skytte established the Skyttean professorship of Eloquence and Government in 1622.

The institutional foundation for political science across Europe and outside Wales and Sweden were nevertheless largely built after World War II. Yet quite a few scientists did modern political science work in the precarious interwar years, but had their careers (or lives) hindered or destroyed by the Nazis. Three colleagues performed pioneering work and who would otherwise be well-known representatives of modern political science.

First, Felix Bernstein (1932) was a professor of statistics at Göttingen, but had a keen interest in analyzing elections. He published an early paper on ecological inference 20 years before Robinson (1950) and Goodman (1953) were able to place their classic studies in the American Sociological Review. Bernstein, whose article was rediscovered by Shively (1985) and Lohmöller and Falter (1986) in the 1980s, survived the Holocaust, but he was forced into exile. ${ }^{1}$

A similar fate befell the Viennese social psychologist Marie Jahoda. Her co-authored study Marienthal: The Sociography of an Unemployed Community (1933) was a landmark microlevel study of the effects of the Great Depression, and seems timelier than ever during the ostensibly unending Great Recession. Jahoda became a professor at NYU, Brunel and Sussex universities after the war.

Finally, Lewis Fry Richardson made contributions to many fields, notably geography, mathematics and meteorology. His pioneering work on arms races and the correlates of war (for example, Richardson 1935, 1948) mainly gained recognition posthumously through the work of Anatol Rapoport (1957), who had returned to Europe in the 1930s to work as a piano player, but fortunately found his way back to the United States and to academia later. ${ }^{2}$

Recent studies show that fascism had a systematic effect on the sciences and was in itself a reason for the growing strength of the United States in academia (Moser, Voena and Waldinger 2014; Waldinger 2010, 2012). The emigration of successful chemists, for instance, increased innovation in the United States by about one-third after 1933 in fields in which the émigrés were active (Moser, Voena and Waldinger 2014). The dismissal of highly productive scientists furthermore darkened the prospects for doctoral students both in terms of promotion and research quality. Waldinger (2010) shows that the firing of professors for racist or political reasons decreased young academics' chances to publish their dissertations, cast a shadow on postdocs' prospects to become full professors and reduced their lifetime citations. The Nazis' ethnic and political cleansing at German universities soon after Hitler's seizure of power also negatively affected the academic output of the top departments (Waldinger 2012). We can be

\footnotetext{
1 Achen and Shively's (1995) study contains a translation of Bernstein's short article.

2 The posthumously published work appeared in Richardson (1960a, 1960b).
} 
sure that similar trends were also manifest in the much smaller social sciences, including our own discipline.

In the years after World War II, for a long time modern political science could not take off. In this grey era following the black period of the sciences under fascism, political science was often relegated to the status of an ancillary discipline and thus subjugated to the trends in supposedly leading subjects such as history or law. The situation started to change in the 1960s, when many political science departments were founded-sometimes as part of new universities, as was the case at my home institution or the University of Essex. However, the expansion of higher education came at the price of decreasing funding. Plümper and Schneider (2007) have demonstrated this empirically for Germany, linking the shrinking expenses per student to increasing unemployment.

The expansion of higher education also increased postdocs' chance of receiving tenure at a young age at the end of the 1960s and the beginning of the 1970s. Many of these promotions took place at the same institutions where they received their doctorates. At the Free University of Berlin, these in-house hires were known as Fahrstuhlprofessors (elevator professors), as they were upgraded virtually overnight from assistant to tenured professors. ${ }^{3}$ These colleagues rarely had a decent publication record, thus it is no wonder that their students seldom performed any better. Academic protectionism hence created an atmosphere of coziness, often binding colleagues with similar worldviews and a shared contempt for academic standards closely together. In this context, it is not surprising that grade inflation is more pronounced in disciplines with a qualitative rather than a quantitative focus (Jewell, McPherson and Tieslau 2013: 1197). ${ }^{4}$

Relying in academic hiring and tenure decisions on criteria other than the applicant's excellence in research and teaching can have disastrous consequences. Rothgeb $(2014,183)$ shows that heads of US political science departments who admit that collegiality matters in their decision making are more likely to admit that "[a]t my college/university, tenure has shielded incompetent faculty from dismissal." The tendency to protect academic underperformers grows with the inclination to rely more on absolute publication counts than on assessments that also take the journal's quality into consideration. Taylor, Fender and Burke (2006) offer similar evidence for the relationship between individual output and the quality of an academic department. According to their evaluation of US economics departments, individual productivity is closely associated with the number of publishing colleagues.

The mistaken tolerance for laziness that many of us have encountered over the years across European academia can be perpetuated only if achievements are not sufficiently rewarded and if promotion is not exclusively based on scholarly merit. A Nobel laureate, the late Gary Becker (1957), convincingly established that shielding a field or industry against competitors with another ethnic background, age or gender is only possible in imperfect markets. ${ }^{5}$ The quite dismal record of political science in gender equality is, in my view, largely due to the impact of unproductive "old boys networks" on our discipline. (Note that fortunately the EPSA leadership

3 The promotion took place automatically without a job advertisement or application letter, but was linked to an habilitation before the expiration of the five-year contract (email correspondence from Michael Bolle, 7 July 2014). Unsurprisingly, the habilitation (second doctorate) itself came under attack as a yardstick for academic promotions. Keller (2000: 20, author's translation) describes it as a "patriarchal initiation rite... which allows the professors to reproduce themselves according to their school, habitus, and gender."

4 Jewell, McPherson and Tieslau (2013: 1198) examined these trends across departments of the University of North Texas, and its political science department exhibited an average trend in grade inflation.

5 I have to note that gender discrimination in hiring decisions is still widespread and can, sadly enough, often be attributed to a lack of gender solidarity. For a systematic analysis of the "queen bee syndrome" in academia, see, for instance, Ellemers et al. (2004). 
now looks much more balanced than some years ago). Unfortunately, I can only report figures about the gender gap in US political science, as no equivalent studies seem to exist for Europe. Hesli, Lee and Mitchell $(2012,485)$ report "a significant advantage for men in the probability of becoming an associate professor, which usually includes tenure," and Maliniak, Powers and Walter (2013) add to this a considerable gender gap in citations in international relations, with men citing themselves and other men more frequently than women with regard to their own work and those of their female colleagues.

An institutional barrier to academic progress, at least in continental Europe, is the chair system. It allows colleagues to delegate much of their research to doctoral students who are still often treated as underlings, who have to completely rely in their career on the continuing support of their employers. As beneficial as the division and delegation of labor might be in some cases, relying on assistants for conducting research makes you lazy and uncompetitive in the long run (Schneider 2011). An evaluation of the publication patterns before and after promotion in German business administration revealed that the median chair holder gives up on publishing in journals indexed in the Social Science Citation index once he or she receives tenure (Röbken 2011).

\section{THE CHANGING LANDSCAPE OF EUROPEAN POLITICAL SCIENCE}

However, times are changing. The chair system is increasingly under pressure, even in as conservative a place as Bavaria, which de facto abandoned it in 2013. Further, funding agencies increasingly require at least some decent publications before splashing out money, and more and more universities have introduced US-style graduate schools. These reforms are root causes of the changes in productivity and efficiency of European political science, which I am happy to report.

Figure 1A shows that the number of articles published by researchers based in Europe is growing. Hence, our field-measured here by counts of articles in journals included in the Social Science Citation index in political science, international relations or public administration-is becoming more productive in absolute terms. ${ }^{6}$ This is certainly due in part to the increasing number of quality journals based in Europe, among them of course EPSA's Political Science Research and Methods, which is too new to contribute to these trends. One might object that absolute productivity does not tell us much about the influence of the articles. According to this adage, the SSCI could be expanding by adding low-impact journals to its list in which mainly Europeans publish. As Figure 1B demonstrates, this does not seem to be the case. Compared to their North American competitors, European-based political scientists have also increased the efficiency of their publication strategies. The increasing average number of citations that articles by European scholars receive is an indication of this trend. The growing h-index of articles by Europe-based authors, summarized in Figure 1C, demonstrates that Europe is also catching up in its ability to produce articles with an eventually high impact. Hence European political science has not only become more efficient, but has also become more excellent. It should be added that this trend happens alongside the continuing domination of the United States and Canada in editing high-impact journals. According to the 2012 ranking, only the Journal of Peace Research was among the top ten political science journals according to the five-year impact factor. A couple of other journals edited in Europe were trailing in the top 20 (European Union Politics, British Journal of Political Science and Scandinavian Political Studies).

The online appendix demonstrates that these developments are consistent across different subfields such as electoral behavior and armed conflict. Finally, the emancipation of European

6 The online appendix provides details about the calculations. 

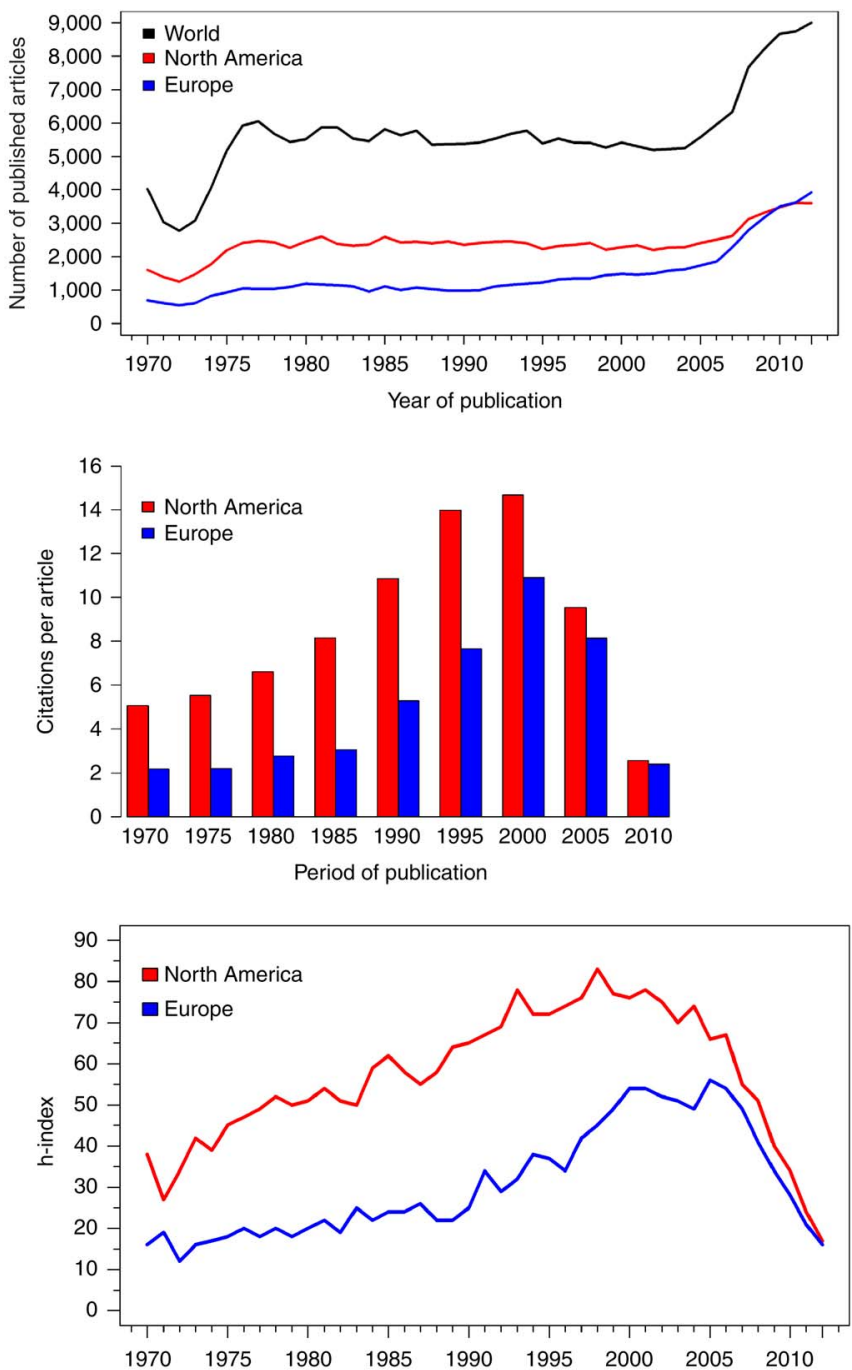

Fig. 1. Productivity and efficiency of European and North American political science. 1A: Number of published articles. 1B: Citations per article. 1C: Hirsch index for articles published in a given year

political science has also reached the field of political methodology. While the substantive focus of methods-based research differs across the Atlantic, European scholars are increasingly conscious that methodological innovations are key for substantive progress.

We are thus witnessing a transformation of political science in some European countries. Figure 2 shows that there are considerable differences in productivity and efficiency across the continent. The Netherlands and the Scandinavian countries top the list of science systems that produce above-average prolific and well-cited scholars. While the United States does very well in absolute terms (and relatively well in relative terms), other large countries such as Germany, Italy and Spain are underperforming. This dismal performance is, at least in the German case, a consequence of the tradition to bury main findings, if they exist at all, in edited volumes or non-English journals that are only read within a narrow internal market and which have, 


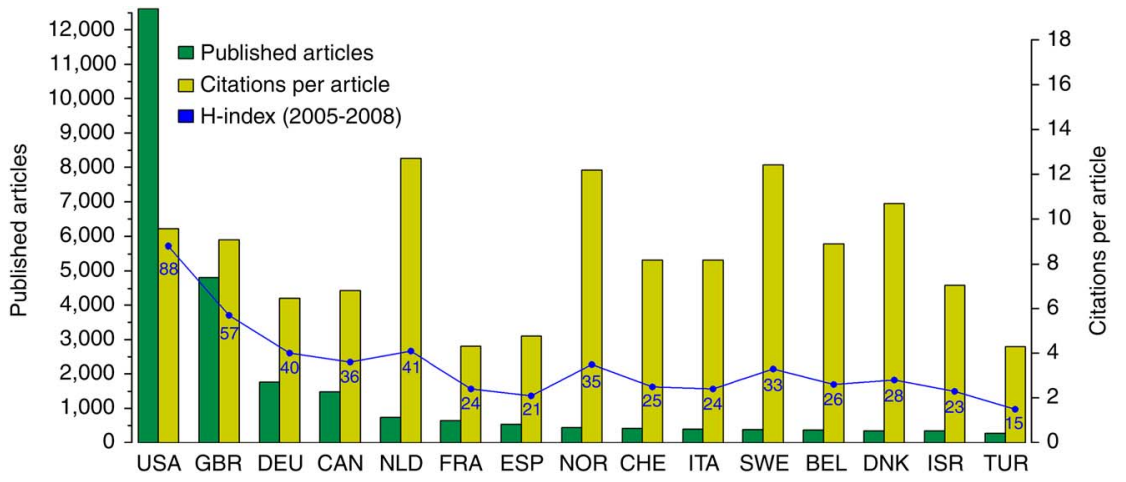

Fig. 2. Number of articles published 2005-09, the citations they received and the H-index per country. Note: The h-index only refers to four years because of limitations of the Web of Knowledge in dealing with a large number of countries.

accordingly, a vanishing impact factor. In an evaluation of research on armed conflict, articles on this topic by Germany-based scholars received the smallest average number of citations across the 20 states included in the analysis. ${ }^{7}$ It is therefore not surprising that the h-index, which measures the ability of a national system of political science to produce high-impact articles, also differs greatly among countries. Note particularly that the small Scandinavian states have very high h-indices, given the size of their populations, while some large science systems have difficulty coming up with influential research. ${ }^{8}$

\section{DETERMINANTS OF SCIENTIFIC EFFECTIVENESS}

While this descriptive evidence is encouraging, we do not fully understand the factors that contribute to the increasing productivity and efficiency of European researchers. Aghion et al. (2010: 46) show in a comparison of US and European institutions of higher education that universities' productivity hinges on both the autonomy they are granted and the competition they face: “... by giving more generous stakes for research competitions, governments can make universities use their funding better, use their autonomy better, and respond more productively to local competition." This suggests, in their view, the need to increase the mobility of students and faculty, and the value of "yardstick competition" programs such as the German excellence initiative or the British Research Excellence Framework. ${ }^{9}$

The academic environment in which we operate makes a difference, and particularly affects our ability to do important research. Williams et al. (2013) show in a highly aggregated analysis that financial resources, as well as the quality of the environment, increase the productivity of

7 The evaluation refers to articles published between 1996 and 2006. Norway tops the ranking with 539 citations for 70 articles (mean 7.7), while German scholars published 163 indexed articles that generated 245 citations, or an average of 1.5 per article. For full details, see http://esi-topics.com/armed-conflict/nations/d1c. html, accessed 9 July 2014.

8 Note that the productive academic systems are also able to attract more of the most prestigious research grants. The Pearson correlation coefficient for the relationship between the number of ERC grants per capita and the average number of citations an article has received is 0.7 .

9 Interestingly, the involvement of German business administration scholars in the excellence initiative did not increase their productivity (Wollersheim et al. forthcoming). 
national academic systems. ${ }^{10}$ To see whether this also holds true for political science, I have calculated bivariate correlations between the quality of the environment indicator and the average number of citations articles published between 2005 and 2009 have received so far. The correlation amounts to 0.33 , and the relationship between the Hirsch index (2005 to 2008) and the environment is of a similar magnitude. Although the scarcity of system-level data on the quality of higher education systems does not allow me to make causal statements, it seems clear that sound policy making can make a difference and improve the lives of educators and students alike.

Also note that universities and their departments can deal with this environment that policy makers set at the national or regional level in different ways. McCormack, Propper and Smith (forthcoming) show the considerable variation in university and departmental management across British higher education. They particularly confirm that autonomy in hiring and rewarding productive scholars increases departments' productivity, while hierarchical incentives (setting of targets, monitoring) mattered less. As continental universities have a lot less financial autonomy, researchers' mobility is reduced. This makes initial hiring decisions much more important. I also note, however, given the increasing requests to write letters of recommendation for universities in a wide variety of countries, that there has been an emergence of a European labor market for political science. I am sure our field would experience another boost in competitiveness if all universities renounced the practice of hiring their own doctoral students for postdocs or even permanent positions.

Obviously, the educational background of individual scholars is also important. Hesli and Lee (2011) show that the rank of a Ph.D. program improves the productivity of US political scientists. This suggests, in the absence of a similar study in Europe, that the introduction of doctoral programs across the old continent will most likely pay off. However, we are well advised not to base our hiring decisions too much on the prestige of the doctoral school, as tardiness in completing the doctorate strongly decreases scholars' productivity.

\section{CONCLUSION}

Let me conclude with three points. First, we are doing much better than I thought. I believe the shift toward a more competitive European political science that we are currently witnessing is largely due to better organization and better journals. Most importantly, perhaps, we have improved our teaching, and this seems to pay off. Second, we should not fall into the trap of EPSA groupthink and believe that the tiresome journey toward a more productive European political science is over. We do not yet have a sufficiently large number of top research outlets, and the labor mobility of European academics is still limited. Some countries, including the one in which I live and work, are still underperforming. Some other countries, which have a huge potential that is not yet fully exploited, have recognized that we need to accept English as the lingua franca of our field. Last year, the Società Italiana di Scienza Politica decided to transform the distinguished Rivista Italiana di Scienza Politica into an all-English journal. ${ }^{11}$

10 The environment index consists of four components: proportion of female students (2009), proportion of female academic staff, quality of data and a "qualitative index of the policy and regulatory environment." The latter indicator, which is weighted with 70 percent for the index, is based on a survey across leading academic institutions. Further information on this ranking can be found at http://www.universitas21.com/, accessed 10 July 2014.

11 As the Bonn emeritus Erich Weede once said, those who publish in non-English journals have something to hide! This suspicion is, in my opinion, true at least for those who almost exclusively publish in minor journals that have a low impact factor, irrespective of the periodical's language. 
I hope the other high-level national outlets such as Politische Vierteljahresschrift or Revue française de science politique, which have not yet embraced the fruits (and pain) of globalization, follow in the footsteps of the Italian reformers. ${ }^{12}$ Third, we cannot only count on efficient organizations like EPSA and ambitious journals like PSRM. We also need to convince funding agencies like the European Research Council that we are doing important research. I see it as my obligation to speak to this increasingly important institution and other key organizations in the coming months, together with some colleagues from EPSA. I am proud to lead this group and to serve for another year as the second president of this organization.

\section{REFERENCES}

Achen, Christopher H., and W. Phillips Shively. 1995. Cross-Level Inference. Chicago: University of Chicago Press.

Philippe Aghion, Mathias Dewatripont, Caroline Hoxby, Andreu Mas-Colell and André Sapir. 2010. 'The Governance and Performance of Universities: Evidence from Europe and the US'. Economic Policy 25(61):7-59.

Becker, Gary S. 1957. The Economics of Discrimination. Chicago: University of Chicago Press.

Bernstein, F(elix). 1932. 'Über eine Methode, die soziologische und bevölkerungsstatistische Gliederung von Abstimmungen bei geheimen Wahlverfahren statistisch zu ermitteln. (About a Method to Statistically Determine the Sociological and Demographic Structure of Votes in Secret Electoral Procedures)'. Allgemeines Statistisches Archiy 22:253-256.

Ellemers, Naomi, Henriette van den Heuvel, Dick de Gilder, Anne Maass, and Alessandra Bonvini. 2004. 'The Underrepresentation of Women in Science: Differential Commitment or the Queen Bee Syndrome?'. British Journal of Social Psychology 43(3):315-338.

Goodman, Leo A. 1953. 'Ecological Regression and Behavior of Individuals'. American Sociological Review 43(6):557-572.

Hesli, Vicki L., and Jae Mook Lee. 2011. 'Faculty Research Productivity: Why Do Some of Our Colleagues Publish More than Others?' PS: Political Science \& Politics 44(2):393-408.

Hesli, Vicki L., Jae Mook Lee, and Sara McLaughlin Mitchell. 2012. 'Predicting Rank Attainment in Political Science: What Else Besides Publications Affects Promotion? PS: Political Science \& Politics 45(3):475-492.

Hoffmann, Stanley. 1977. 'An American Social Science: International Relations'. Daedalus 106(3):41-60.

Jahoda, Marie, Paul F. Lazarsfeld, and Zeisel. 1933. Die Arbeitslosen von Marienthal. Ein soziographischer Versuch über die Wirkungen langandauernder Arbeitslosigkeit. Leipzig: Hirzel. (The Unemployed of Marienthal. A Sociographic Attempt about the Effects of Long-Term Unemployment. Trans. Published in 2002 as Marienthal: The Sociography of an Unemployed Community, Transaction Publishers).

Jewell, R. Todd, Michael A. McPherson, and Margie A. Tieslau. 2013. 'Whose Fault Is It? Assigning Blame for Grade Inflation in Higher Education'. Applied Economics 45(9):1185-1200.

Keller, Andreas. 2000. 'Ein uneingelöstes Vermächtnis. Konzeptionen zur Reform der Personalstruktur an Hochschulen seit 1968 (An unredeemed promise: Concepts for the reform of the personnel structure at universities since 1968)'. Hochschule Ost 00(3-4):15-29.

Lohmöller, Jan-Bernd, and Jürgen W. Falter. 1986. 'Some Further Aspects of Ecological Regression Analysis'. Quality and Quantity 20(1):109-125.

Maliniak, Daniel, Ryan Powers, and Barbara F. Walter. 2013. 'The Gender Citation Gap in International Relations'. International Organization 67(4):889-922.

McCormack, John, Carole Propper, and Sarah Smith. Forthcoming. Herding Cats? Management and University Performance'. Economic Journal, doi: 10.1111/ecoj.12105.

12 I add with satisfaction that other journals of national political science associations, including the Dutch Acta Politica, moved in this direction quite some time ago. 
Merton, Robert K. 1968. 'The Matthew Effect in Science'. Science 159(3810):56-63.

Moser, Petra, Alessandra Voena, and Fabian Waldinger. 2014. 'German-Jewish Émigrés and U.S. Invention'. American Economic Review, in print.

Plümper, Thomas, and Christina Schneider. 2007. 'Too Much to Die, Too Little to Live: Unemployment, Higher Education Policies and University Budgets in Germany'. Journal of European Public Policy 14(4):631-653.

Rapoport, Anatol. 1957. 'Lewis F. Richardson's Mathematical Theory of War'. Journal of Conflict Resolution 1:249-299.

Richardson, Lewis F. 1935. 'Mathematical Psychology of War'. Nature 135:830-831.

- 1948. 'Variation of the Frequency of Fatal Quarrels with Magnitude'. Journal of the American Statistical Association 43(244):523-546.

- 1960a. Arms and Insecurity: A Mathematical Study of the Causes and Origins of War, Ed. Nicolas Rashevsky and Ernesto Trucco. Chicago: Quadrangle.

— 1960b. Statistics of Deadly Quarrels, Ed. by Quincy Wright and C. C. Lienau. Chicago: Quadrangle.

Robinson, William S. 1950. 'Ecological Correlations and the Behavior of Individuals'. American Sociological Review 15(3):351-357.

Röbken, Heinke. 2011. 'Forschungsproduktivität von Wissenschaftlern und Wissenschaftlerinnen. Eine empirische Analyse von Publikationsaktivitäten vor und nach der Berufung (Research Productivity of Male and Female Scientists. An Empirical Analysis of Publication Activities before and after an Appointment as Professor)'. Beiträge zur Hochschulforschung 33(3):62-81.

Rothgeb, John M. 2014. 'When Tenure Protects the Incompetent: Results from a Survey of Department Chairs'. PS: Political Science \& Politics 47(1):182-187.

Schneider, Gerald. 2007. 'Why is European Political Science so Unproductive and What Should be Done about It: A Symposium'. European Political Science 6(2):156-159.

2011. 'How to Avoid the Seven Deadly Sins of Academic Writing'. European Political Science 10(3):337-345.

Shively, W. Philips. 1985. 'A Strategy for Cross-Level Inference under an Assumption of Breakage Effects'. Political Methodology 11(3/4):167-179.

Taylor, Susan Washburn, Blakely Fox Fender, and Kimberly Gladden Burke. 2006. 'Unraveling the Academic Productivity of Economists: The Opportunity Costs of Teaching and Service'. Southern Economic Journal 72(4):846-859.

Waldinger, Fabian. 2010. 'Quality Matters: The Expulsion of Professors and the Consequences for Ph.D. Student Outcomes in Nazi Germany'. Journal of Political Economy 118(4):787-831.

2012. 'Peer Effects in Science - Evidence from the Dismissal of Scientists in Nazi Germany'. Review of Economic Studies 79(2):838-886.

Williams, Ross, Gaétan de Rassenfosse, Paul Jensen, and Simon Marginson. 2013. 'The Determinants of Quality National Higher Education Systems'. Journal of Higher Education Policy and Management 35(6):599-611.

Wollersheim, Jutta, Annett Lenz, Isabell M. Welpe, and Matthias Spörle. Forthcoming. Me, Myself, and My University: A Multilevel Analysis of Individual and Institutional Determinants of Academic Performance'. Journal of Business Economics. 